\title{
Manoalide Preferentially Provides Antiproliferation of Oral Cancer Cells by Oxidative Stress-Mediated Apoptosis and DNA Damage
}

\author{
Hui-Ru Wang ${ }^{1}$, Jen-Yang Tang ${ }^{2,3}$, Yen-Yun Wang ${ }^{4,5,6}$, Ammad Ahmad Farooqi ${ }^{7}$, Ching-Yu Yen ${ }^{8}$, \\ Shyng-Shiou F. Yuan ${ }^{4,6,9}$, Hurng-Wern Huang ${ }^{1, *}$ and Hsueh-Wei Chang $4,6,10,11,12, *$ (1) \\ 1 Institute of Biomedical Science, National Sun Yat-sen University, Kaohsiung 80424, Taiwan \\ 2 Department of Radiation Oncology, Faculty of Medicine, College of Medicine, Kaohsiung Medical \\ University, Kaohsiung 80708, Taiwan \\ 3 Department of Radiation Oncology, Kaohsiung Medical University Hospital, Kaohsiung 80708, Taiwan \\ 4 Cancer Center, Kaohsiung Medical University Hospital, Kaohsiung Medical University, \\ Kaohsiung 80708, Taiwan \\ 5 School of Dentistry, College of Dental Medicine, Kaohsiung Medical University, Kaohsiung 80708, Taiwan \\ 6 Center for Cancer Research, Kaohsiung Medical University, Kaohsiung 80708, Taiwan \\ 7 Department of Molecular Oncology, Institute of Biomedical and Genetic Engineering (IBGE), \\ Islamabad 54000, Pakistan \\ 8 Department of Oral and Maxillofacial Surgery Chi-Mei Medical Center, Tainan 71004, Taiwan \\ 9 Translational Research Center, Kaohsiung Medical University Hospital, Kaohsiung 80708, Taiwan \\ 10 Department of Medical Research, Kaohsiung Medical University Hospital, Kaohsiung 80708, Taiwan \\ 11 Institute of Medical Science and Technology, National Sun Yat-sen University, Kaohsiung 80424, Taiwan \\ 12 Department of Biomedical Science and Environmental Biology, Kaohsiung Medical University, \\ Kaohsiung 80708, Taiwan \\ * Correspondence: sting@mail.nsysu.edu.tw (H.-W.H.); changhw@kmu.edu.tw (H.-W.C.); \\ Tel.: +886-7-525-2000 (ext. 5814) (H.-W.H.); +886-7-312-1101 (ext. 2691) (H.-W.C.); \\ Fax: +886-7-525-0197 (H.-W.H.); +886-7-312-5339 (H.-W.C.)
}

Received: 15 May 2019; Accepted: 2 September 2019; Published: 4 September 2019

\begin{abstract}
Marine sponge-derived manoalide has a potent anti-inflammatory effect, but its potential application as an anti-cancer drug has not yet been extensively investigated. The purpose of this study is to evaluate the antiproliferative effects of manoalide on oral cancer cells. MTS assay at $24 \mathrm{~h}$ showed that manoalide inhibited the proliferation of six types of oral cancer cell lines (SCC9, HSC3, OC2, OECM-1, Ca9-22, and CAL 27) but did not affect the proliferation of normal oral cell line (human gingival fibroblasts (HGF-1)). Manoalide also inhibits the ATP production from 3D sphere formation of Ca9-22 and CAL 27 cells. Mechanically, manoalide induces subG1 accumulation in oral cancer cells. Manoalide also induces more annexin V expression in oral cancer Ca9-22 and CAL 27 cells than that of HGF-1 cells. Manoalide induces activation of caspase 3 (Cas 3), which is a hallmark of apoptosis in oral cancer cells, Ca9-22 and CAL 27. Inhibitors of Cas 8 and Cas 9 suppress manoalide-induced Cas 3 activation. Manoalide induces higher reactive oxygen species (ROS) productions in Ca9-22 and CAL 27 cells than in HGF-1 cells. This oxidative stress induction by manoalide is further supported by mitochondrial superoxide (MitoSOX) production and mitochondrial membrane potential (MitoMP) destruction in oral cancer cells. Subsequently, manoalide-induced oxidative stress leads to DNA damages, such as $\gamma \mathrm{H} 2 \mathrm{AX}$ and 8-oxo-2'-deoxyguanosine (8-oxodG), in oral cancer cells. Effects, such as enhanced antiproliferation, apoptosis, oxidative stress, and DNA damage, in manoalide-treated oral cancer cells were suppressed by inhibitors of oxidative stress or apoptosis, or both, such as $\mathrm{N}$-acetylcysteine (NAC) and Z-VAD-FMK (Z-VAD). Moreover, mitochondria-targeted superoxide inhibitor MitoTEMPO suppresses manoalide-induced MitoSOX generation and $\gamma \mathrm{H} 2 \mathrm{AX} / 8$-oxodG DNA damages. This study validates the preferential antiproliferation effect of manoalide and explores the oxidative stress-dependent mechanisms in anti-oral cancer treatment.
\end{abstract}


Keywords: marine sponge; natural product; anticancer drug; oral cancer inhibition

\section{Introduction}

Oral cancer is one of the high incidence cancers worldwide [1], especially in Southeast Asia and Taiwan. Betel quid chewing, smoking, and alcohol consumption are high risk factors for oral cancer [2]. Oral cancer causes serious morbidity and mortality [3]. Current therapies for oral cancer patients include surgery or chemoradiation, or both. However, chemoradiation commonly shows severe side effects in oral cancer patients [4]. Therefore, continuous drug screening and development for oral cancer therapy remains a challenge.

Marine natural products provide an abundant resource for development of anti-cancer agents [5-8]. Besides corals, marine sponges provide diverse sources of natural products from the ocean. Marine sponges are marine resources with a wide range of bioactive compounds and secondary metabolites with potential therapeutic effects [9-11]. Bioactive compounds of marine sponges and their microbial consortia are known for their anticancer, anti-inflammatory, antiviral, and antibiotic effects [11,12].

In 1980, manoalide, an antibiotic sesterterpenoid isolated from the marine sponge Luffariella variabilis, was discovered [13]. In 1999, manoalide was reported to function as an analgesic and anti-inflammatory agent [14]. This anti-inflammatory effect may be caused by the inhibition of phospholipase A2 (PLA2) by manoalide [14]. Moreover, manoalide also functions as inhibitors for phospholipase C (PLC) [15,16] and calcium channels [17]. Manoalide reached Phase II (antipsoriatic) clinical trial, although it was discontinued due to formulation problems [18].

In addition to anti-inflammatory effects, the anti-cancer effects of manoalide have not been extensively studied. For example, manoalide showed a cytotoxic effect against murine lymphoma LI210 and human epidermoid carcinoma KB cells [19]. However, the anticancer effect against oral cancer cells was not studied as yet.

Natural products, such as marine sponges, commonly showed antioxidant properties [20,21]. Some marine sponge-derived natural products showed both cytotoxic and antioxidant activities [22-24]. Manoalide inhibits superoxide production in colon cancer cells (HT29-D4) [25], suggesting that manoalide may have an antioxidant potential. Interestingly, antioxidants possess double-edge sword activities to regulate cellular reactive oxygen species (ROS). For example, antioxidants at physiological concentrations may decrease ROS and benefit cell health but induce ROS that damage cells at high concentrations [26]. Hence, the ROS modulating effect of manoalide on oral cancer cells warrants further investigation. Furthermore, drugs with inducing ROS generation ability may preferentially kill cancer cells but show little damage to normal cells [27]. Whether manoalide causes a preferential killing to oral cancer cells needs further to be examined.

In this study, we hypothesized that manoalide may preferentially inhibit the proliferation of oral cancer cells. To examine this hypothesis, the preferential antiproliferation effect of manoalide on oral cancer cells was studied by analyzing cell survival, cell cycle, apoptosis, oxidative stress, and DNA damage.

\section{Results}

2.1. Cell Viability of Manoalide-Treated Oral Cancer and Normal Oral Cells with or Without Pretreatments of NAC or Z-VAD

Cell viability was determined by mitochondrial enzyme activity-based MTS assay. Figure 1A shows that manoalide dose-responsively decreases the viability (\%) of oral cancer cells (CAL 27, Ca9-22, HSC3, OECM-1, SCC9, and OC-2), but it only slightly decreases oral normal cells (human gingival fibroblasts (HGF-1)), i.e., their $\mathrm{IC}_{50}$ values of manoalide are 7.8, 9.1, 14.9, 17.4, and $18.5 \mu \mathrm{M}$ at $24 \mathrm{~h}$ MTS assay. Among the oral cancer cells, Ca9-22 and CAL 27 cells belong to different oral locations (gingival 
and tongue) and show higher cytotoxicity upon manoalide treatment. Accordingly, Ca9-22 and CAL 27 cells were selected for the following assays to investigate the detailed mechanisms of anti-oral cancer cells by manoalide. Figure $1 \mathrm{~B}$ shows that 48 and $72 \mathrm{~h}$ treatments of manoalide dose-responsively decrease the viability (\%) of oral cancer cells, but it only slightly decreases oral normal cells (HGF-1), i.e., the $\mathrm{IC}_{50}$ values of manoalide-treated oral cancer Ca9-22 and CAL 27 cells are 5.3 versus $14.0 \mu \mathrm{M}$ and 3.1 versus $7.5 \mu \mathrm{M}$ at 48 and $72 \mathrm{~h}$ MTS assay, respectively. Furthermore, the photo images of 3D sphere formation pattern of oral cancer cells are provided (Figure S1A). Its cell viability needs to be determined by ATP detection. As shown in Figure 1C, the ATP-detected 3D sphere formation ability of oral cancer cells (Ca9-22 and CAL 27) was decreased by manoalide treatment.

To address the role of oxidative stress and apoptosis in cell viability, the ROS scavenger $\mathrm{N}$-acetylcysteine (NAC) [28,29] and apoptosis inhibitor Z-VAD-FMK (Z-VAD) [30] were used. The cell morphologies were abnormal in manoalide-treated oral cancer (Ca9-22 and CAL 27) cells, especially at higher concentrations (Figure S1B). However, these manoalide-induced abnormal changes on morphologies were recovered by NAC pretreatment and partly recovered by Z-VAD pretreatment (Figure S1B). Moreover, manoalide-suppressed cell viabilities in oral cancer cells were completely inhibited by a NAC pretreatment and partly inhibited by a Z-VAD pretreatment (Figure 1D).

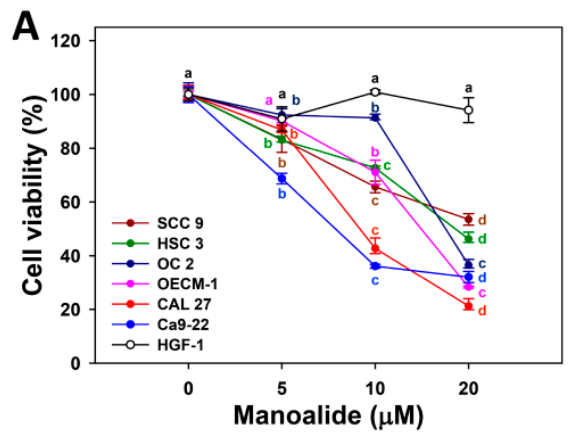

B
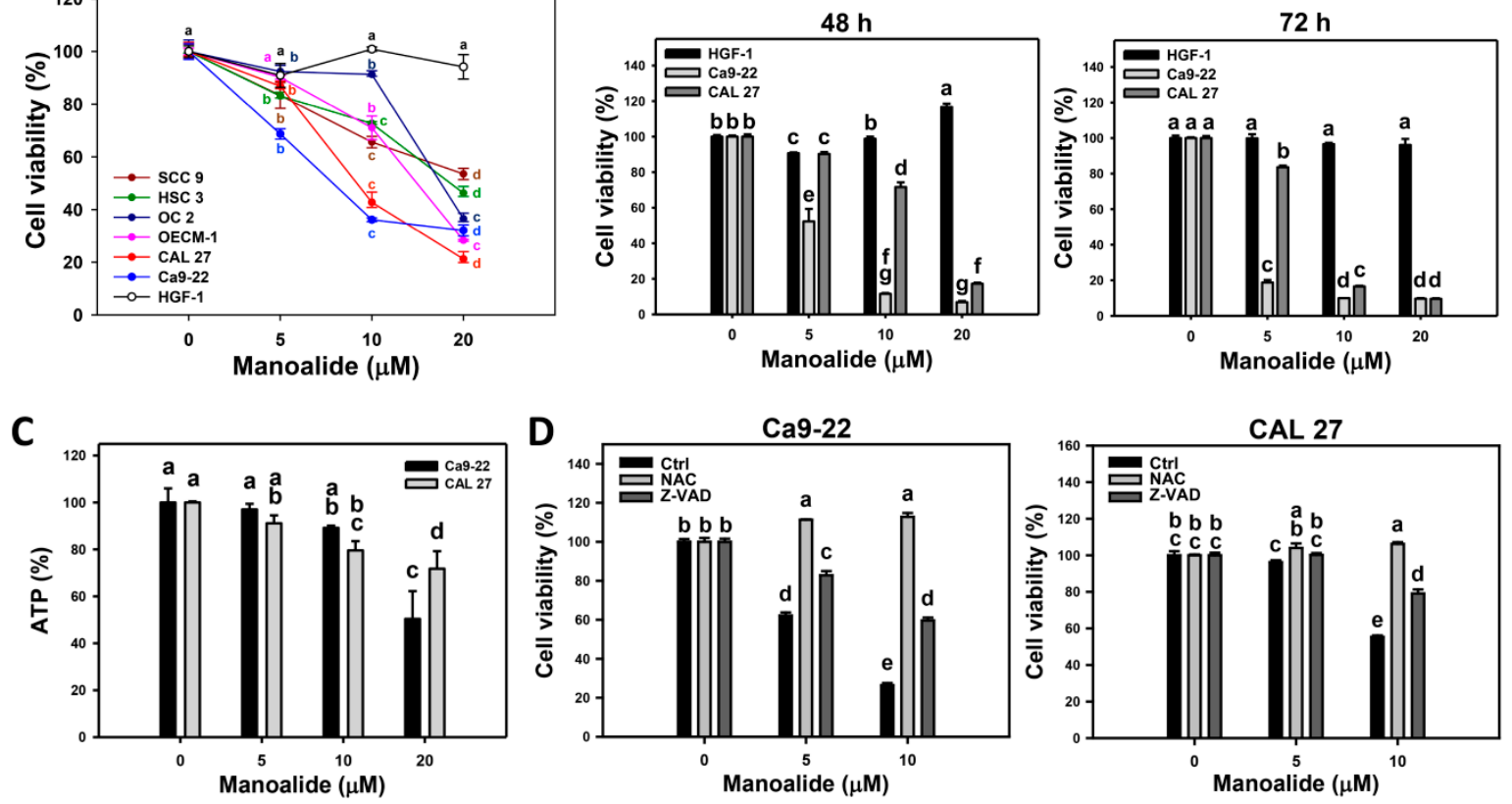

Figure 1. Cell viabilities of oral cancer cells after manoalide treatment and its $N$-acetylcysteine (NAC)/apoptosis inhibitor Z-VAD-FMK (Z-VAD) effects. Cells were treated with $0,5,10$, and $20 \mu \mathrm{M}$ of manoalide. All treatments have the same concentration of DMSO. (A) MTS assay-based cell viabilities for $24 \mathrm{~h}$. Oral cancer (CAL 27, Ca9-22, OECM-1, OC-2, HSC 3, and SCC9) cells and oral normal (HGF-1) cells were included. (B) MTS assay-based cell viabilities for 48 and $72 \mathrm{~h}$ for oral cancer (CAL 27 and Ca9-22) and oral normal (HGF-1) cells. (C) Statistical of 3D spheroid formation for manoalide-treated oral cancer (Ca9-22 and CAL 27) cells for $72 \mathrm{~h}$. (D) NAC and Z-VAD effects on MTS viability of manoalide-treated oral cancer cells. Pretreatment conditions were $8 \mathrm{mM}, 1 \mathrm{~h}$ for NAC and $100 \mu \mathrm{M}, 2 \mathrm{~h}$ for Z-VAD. Following pretreatment or not, oral cancer (Ca9-22 and CAL 27) cells were post-incubated with 5 and $10 \mu \mathrm{M}$ manoalide for $24 \mathrm{~h}$. Data, means \pm SDs $(n=3)$. Data were analyzed by one-way ANOVA with Tukey HSD Post Hoc Test. Data showing the same small lettersrepresent nonsignificant differences whereas data showing no overlapping same small letters are significant difference $(p<0.05-0.001)$. 


\subsection{Cell Cycle Changes of Manoalide-Treated Oral Cancer Cells with or Without Pretreatments of NAC or Z-VAD}

7-Aminoactinomycin D (7AAD) is a DNA staining dye for measuring the different cell cycle phases. Figure S2A shows the pattern changes of cell cycle progression for oral cancer cells (Ca9-22 and CAL 27) after manoalide treatment. The subG1 and $>4 \mathrm{~N}$ populations appear at 10 and $20 \mu \mathrm{M}$ of manoalide for Ca9-22 cells and at $20 \mu \mathrm{M}$ for CAL 27 cells. Figure 2A shows that the subG1 populations are increased after manoalide treatment.

To address the role of oxidative stress and apoptosis in cell cycle distribution, the NAC and Z-VAD were used. Figure S2B shows the effect of NAC and Z-VAD pretreatments on pattern of cell cycle progression for manoalide-treated oral cancer cells and shows cell cycle disturbances (subG1 and $>$ $4 \mathrm{~N}$ populations). Figure 2B shows these manoalide-induced subG1 accumulations were recovered by NAC pretreatment and partly recovered by Z-VAD pretreatment.
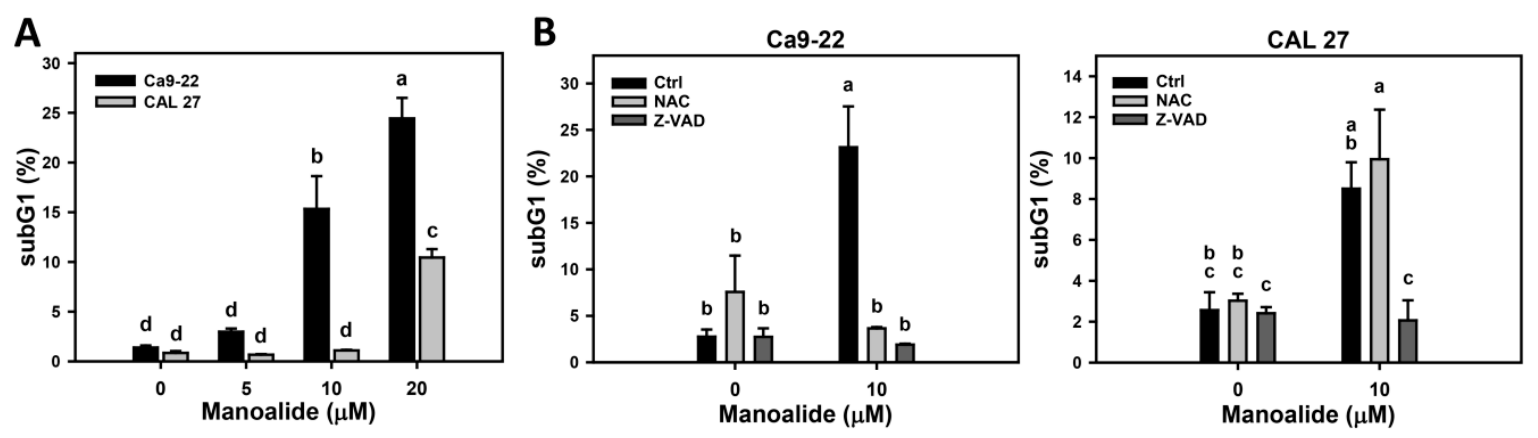

Figure 2. Cell cycle changes of manoalide-treated oral cancer (Ca9-22 and CAL 27) cells. (A) Statistical results of the subG1 (\%) for manoalide-treated oral cancer cells in Figure S2A. Cells were treated with $0,5,10$, and $20 \mu \mathrm{M}$ of manoalide for $24 \mathrm{~h}$. (B) Statistical result of the subG1 (\%) for NAC, Z-VAD, and/or manoalide-treated oral cancer cells in Figure S2B. Cells were pretreated with $8 \mathrm{mM}, 1 \mathrm{~h}$ for NAC or $100 \mu \mathrm{M}$ and $2 \mathrm{~h}$ for Z-VAD, and they were then post-incubated with $10 \mu \mathrm{M}$ of manoalide for $24 \mathrm{~h}$. Data, means \pm SDs $(n=3)$. Data were analyzed by one-way ANOVA with Tukey HSD Post Hoc Test. Data showing no overlapping same small letters represent significant difference $(p<0.05-0.001)$.

\subsection{Apoptosis of Manoalide-Treated Oral Cancer Cells with or Without Pretreatments of NAC or Z-VAD}

Apoptosis was detected by the annexin V/7AAD method. Figure S3A shows that the populations of oral cancer (Ca9-22 and CAL 27) cells shift from annexin V (-)/7ADD (-) to annexin V (+)/7ADD (-) at $5 \mu \mathrm{M}$ of manoalide and further shift to annexin $\mathrm{V}(+) / 7 \mathrm{ADD}(+)$ at 10 and $20 \mu \mathrm{M}$. In contrast, normal oral cells (HGF-1) show only a slight shift to apoptosis region. Therefore, cell populations of oral cancer cells shift from alive, early apoptosis, to late apoptosis when the concentrations of manoalide increase. Figure $3 \mathrm{~A}$ shows that manoalide mainly induces early apoptosis at $5 \mu \mathrm{M}$, moderately induces late apoptosis at $10 \mu \mathrm{M}$, and mainly induces late apoptosis at $20 \mu \mathrm{M}$ in oral cancer cells. However, manoalide-treated HGF-1 cells induce little apoptosis, which is undetectable at 5 and $10 \mu \mathrm{M}$ and is less than $15 \%$ for early apoptosis at $20 \mu \mathrm{M}$.

The involvement of oxidative stress in the apoptosis for manoalide-treated oral cancer cells were further examined (Figure S3B and Figure 3B). Figure S3B shows that the populations of manoalide-induced late apoptosis shift to early apoptosis or living status by NAC or Z-VAD pretreatment. Figure 3B shows that NAC or Z-VAD pretreatments decrease the manoalide-induced apoptosis for both oral cancer cells, Ca9-22 and CAL 27.

To further validate that apoptosis is induced by manoalide in oral cancer cells, western blotting analysis was performed. Figure $3 \mathrm{C}$ shows that manoalide induces overexpression of cleaved forms of caspase 3 (c-Cas 3) in both oral cancer cells, Ca9-22 and CAL 27. Figure S4A showing the procaspase 3 and c-Cas 3 patterns also supports this finding. Moreover, this manoalide-induced c-Cas 3 is 
suppressed by NAC or Z-VAD pretreatments in both oral cancer cells, Ca9-22 and CAL 27 (Figure 3D). All the raw data for western blotting are provided (Figures S4B and S5).

To identify the initiator caspase responsible for the activation of Cas-3, the involvements of Cas 8 and Cas 9 were examined by using its inhibitors [31]. Figure S6A shows that the immunofluorescence of c-Cas 8- and c-Cas 9-staining of manoalide-treated oral cancer cells is higher than the control. Figure S6B shows that the populations of manoalide-induced c-Cas 3 shift to a low level by pretreatments of Cas 8 or Cas 9 inhibitors. Figure 3E shows that Cas 8 or Cas 9 inhibitor pretreatments decrease the manoalide-induced c-Cas 3 activation for both oral cancer cells, Ca9-22 and CAL 27, suggesting that initiator caspase, such as both Cas 8 and Cas 9, are responsible for the c-Cas-3 activation in manoalide-treated oral cancer cells.

A
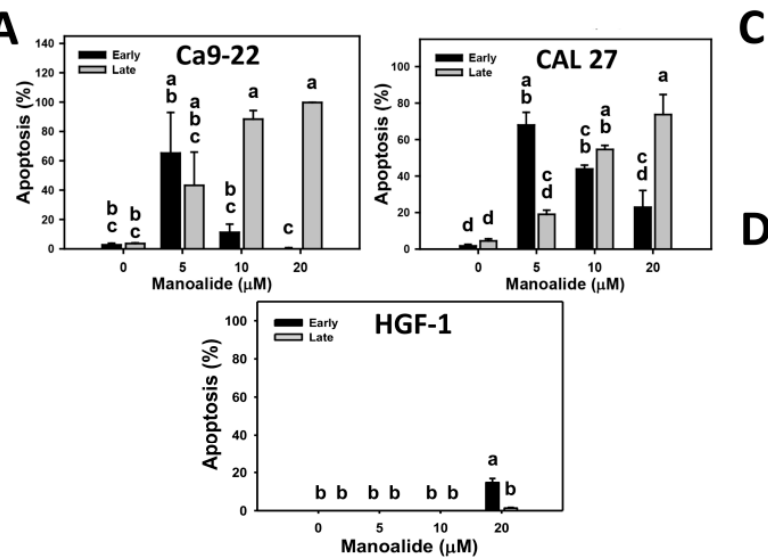

B
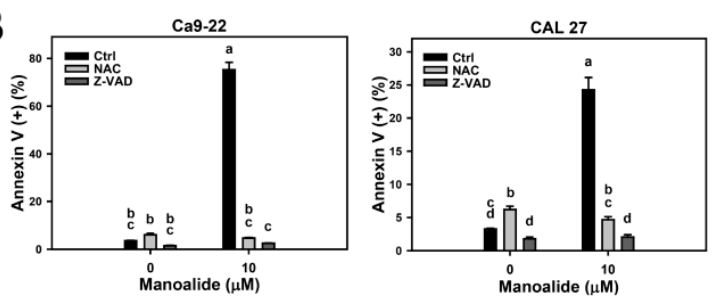

C
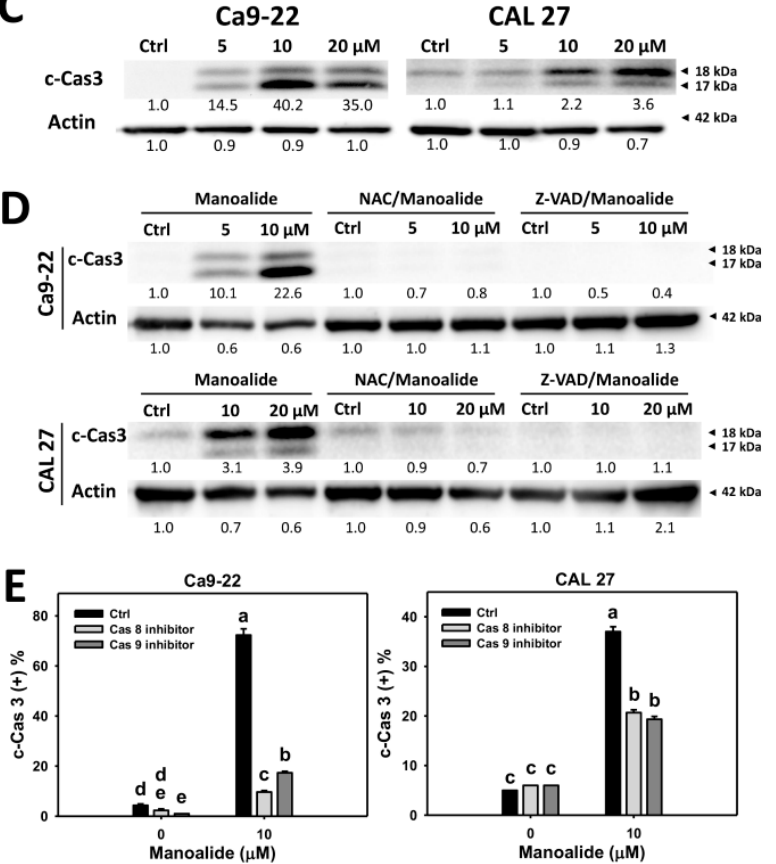

Figure 3. Apoptosis changes in manoalide-treated oral cancer (Ca9-22 and CAL 27) cells and normal oral (HGF-1) cells. (A) Statistical results of the annexin V/7AAD method in manoalide-treated oral cancer cells and normal oral (HGF-1) cells in Figure S3A. Cells were treated with different concentrations of manoalide for $24 \mathrm{~h}$. Early and late apoptosis were, respectively, counted by the populations in the annexin $\mathrm{V}(+) / 7 \mathrm{AAD}(-)$ and annexin $\mathrm{V}(+) / 7 \mathrm{AAD}(+)$ regions, i.e., Q3 and Q2. (B) Statistics results of annexin V/7AAD method in NAC, Z-VAD, and/or manoalide-treated oral cells in Figure S3B. Cells were pretreated with NAC ( $8 \mathrm{mM}, 1 \mathrm{~h})$ or Z-VAD $(100 \mu \mathrm{M}, 2 \mathrm{~h})$, and posttreated with manoalide $(10 \mu \mathrm{M}$, $24 \mathrm{~h})$. Apoptosis was represented by the sum of early and late apoptosis, i.e., annexin V (+)/7AAD (+ or - ). (C) Western blotting for detecting apoptosis in manoalide-treated oral cancer cells. (D) Western blotting for detecting apoptosis in NAC, Z-VAD, and/or manoalide-treated oral cells. Cleaved forms caspase 3 (c-Cas 3) were used to detect apoptosis. Actin was the internal control. (E) Statistical results of c-Cas 3 positive levels in Cas 8 inhibitor, Cas 9 inhibitor, and/or manoalide-treated oral cells in Figure S6. Cells were pretreated with Cas 8 inhibitor Z-IETD-FMK $(100 \mu \mathrm{M}, 2 \mathrm{~h})$ or Cas 9 inhibitor Z-LEHD-FMK $(100 \mu \mathrm{M}, 2 \mathrm{~h})$, and posttreated with manoalide $(10 \mu \mathrm{M}, 24 \mathrm{~h})$. Data were analyzed by one-way ANOVA with Tukey HSD Post Hoc Test. Data, means \pm SDs $(n=3)$. Data showing no overlapping same small letters represent significant difference $(p<0.05-0.001)$.

\subsection{ROS Production of Manoalide-Treated Oral Cancer and Normal Oral Cells}

$2^{\prime}, 7^{\prime}$-dichlorodihydrofluorescein diacetate (DCFH-DA) can react with ROS to generate products for flow cytometry detection [32]. Figure S7A shows the ROS patterns of manoalide-treated oral cancer (Ca9-22 and CAL 27) and normal oral (HGF-1) cells. Figure 4A shows that the ROS productions of 
Ca9-22 and CAL 27 cells are dramatically induced when the concentrations of manoalide increase. In contrast, the ROS productions of HGF-1 cells stay unchanged at $5 \%$, at less than $10 \mu \mathrm{M}$ and slightly increased to $25 \%$ at $20 \mu \mathrm{M}$.

To address the role of oxidative stress and apoptosis in manoalide-induced ROS production, pretreatments of NAC and Z-VAD were used, and its ROS patterns were shown in Figure S7B. Figure 4B shows that the manoalide-induced ROS productions are inhibited by NAC and Z-VAD pretreatments for both oral cancer cells, Ca9-22 and CAL 27.
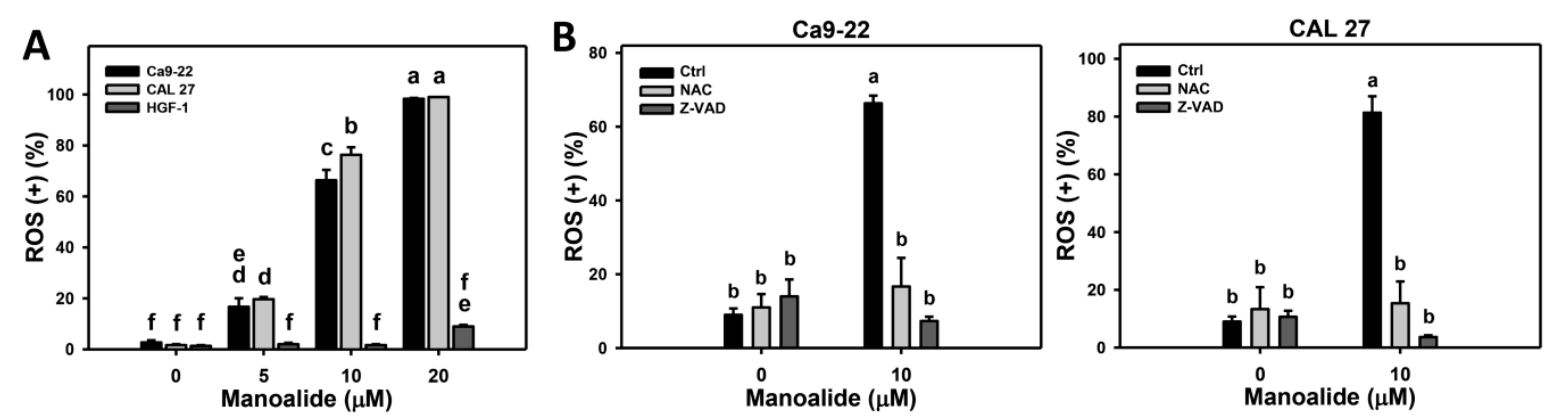

Figure 4. ROS changes in manoalide-treated oral cancer (Ca9-22 and CAL 27) and normal oral (HGF-1) cells. Cells were treated with different concentrations of manoalide for $10 \mathrm{~min}$. (A). Statistical results of ROS (+) (\%) for manoalide-treated oral cancer and oral normal cells in Figure S7A. (B) Statistical results in NAC, Z-VAD, and/or manoalide-treated oral cells in Figure S7B. Cells were pretreated with NAC ( $8 \mathrm{mM}, 1 \mathrm{~h})$ or Z-VAD $(100 \mu \mathrm{M}, 2 \mathrm{~h})$, and posttreated with manoalide (10 $\mu \mathrm{M}, 10 \mathrm{~min})$. Data were analyzed by one-way ANOVA with Tukey HSD Post Hoc Test. Data, means \pm SDs $(n=3)$. Data showing no overlapping same small letters represent significant differences $(p<0.05-0.001)$.

2.5. Mitochondrial Superoxide (MitoSOX) Production of Manoalide-Treated Oral Cancer Cells with or Without Pretreatment of MitoTEMPO

MitoSOX ${ }^{\mathrm{TM}}$ Red can react with intra-mitochondrial superoxide to generate products for flow cytometry detection [33]. Figure S8A shows the populations of oral cancer (Ca9-22 and CAL 27) cells shift to MitoSOX (+) region when the concentrations of manoalide increase. Figure $5 \mathrm{~A}$ shows that the MitoSOX production of Ca9-22 and CAL 27 cells dramatically increase. Figure S8B shows the positive control treatment (betulinic acid; BA) [34] for MitoSOX patterns in oral cancer. Figure 5B shows that the manoalide induces more MitoSOX productions than that of BA in Ca9-22 and CAL 27 cells.

Moreover, the involvement of MitoSOX in manoalide-treated oral cancer cells was further validated using MitoSOX inhibitor (MitoTEMPO). Figure S8C shows the MitoSOX patterns of MitoTEMPO pretreatment effects against manoalide-treated oral cancer cells. Figure 5C shows that MitoTEMPO pretreatment decreases the manoalide-induced MitoSOX production for both oral cancer cells, Ca9-22 and CAL 27. 

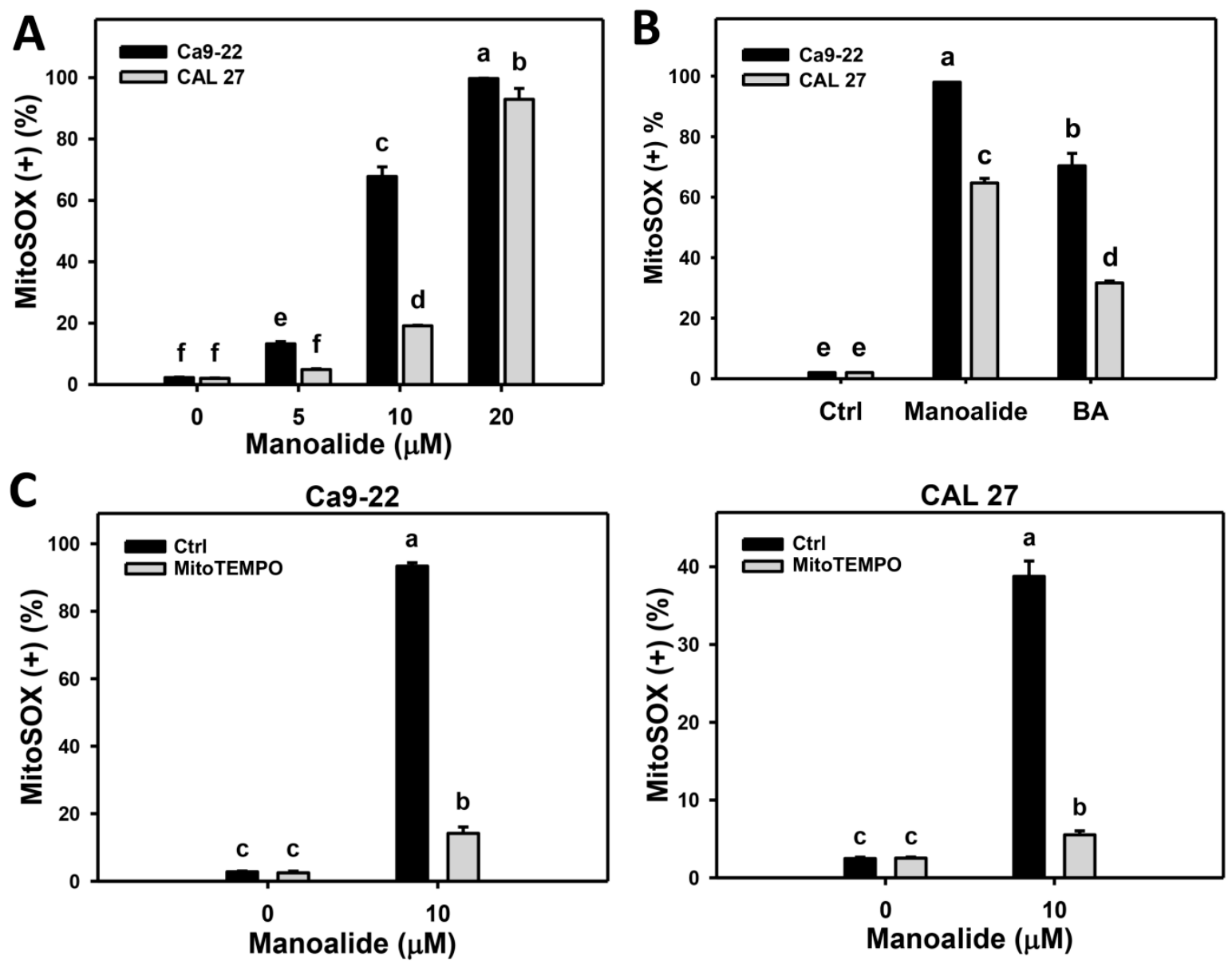

Figure 5. Change of mitochondrial superoxide (MitoSOX) production in manoalide-treated oral cancer (Ca9-22 and CAL 27) cells. (A) Statistical results of MitoSOX (+) (\%) for manoalide-treated oral cancer cells in Figure S8A. Cells were treated with different concentrations of manoalide for $24 \mathrm{~h}$. (B) Statistical results of positive control of MitoSOX (+) (\%) for oral cancer cells in Figure S8B. Cells were treated with betulinic acid (BA; $25 \mu \mathrm{M}, 24 \mathrm{~h}$ ) as the positive control treatment for comparison to manoalide (10 $\mu \mathrm{M}, 24 \mathrm{~h})$. (C) Statistical results of MitoSOX (+) (\%) in MitoSOX inhibitor (MitoTEMPO) and/or manoalide-treated oral cells in Figure S8C. Cells were pretreated with MitoTEMPO $(20 \mu \mathrm{M}, 1 \mathrm{~h})$ and posttreated with manoalide $(10 \mu \mathrm{M}, 24 \mathrm{~h})$. Data were analyzed by one-way ANOVA with Tukey HSD Post Hoc Test. Data, means \pm SDs $(n=3)$. Data showing no overlapping same small letters represent significant difference $(p<0.05-0.001)$.

\subsection{Membrane Potential (MitoMP) of Manoalide-Treated Oral Cancer Cells with or Without Pretreatments of} NAC or Z-VAD

JC-1 aggregate (red fluorescent) form can concentrate at mitochondria, and JC-1 monomer form (green fluorescent) escape from mitochondria, reflecting the intact and depolarized MitoMP, respectively [35]. These fluorescent signals were detected by flow cytometry. Figure S9A shows that the populations of oral cancer (Ca9-22 and CAL 27) cells shift from JC-1 aggregates MitoMP (+) to JC-1 monomers MitoMP (-) region when the concentrations of manoalide increase. Figure 6A shows that the JC-1 monomers MitoMP (-) population is dose-responsively increased in manoalide-treated oral cancer cells. Figure S9B shows the positive control treatment (betulinic acid; BA) for MitoMP patterns in oral cancer. Figure $6 \mathrm{~B}$ shows that the manoalide induces more JC-1 monomers MitoMP (-) productions than that of BA in Ca9-22 and CAL 27 cells.

To address the role of oxidative stress and apoptosis in manoalide-suppressed MitoMP, pretreatments of NAC and Z-VAD were used and its MitoMP patterns are shown in Figure S9C. 
Figure $6 \mathrm{C}$ shows that the manoalide-induced JC- 1 monomer generations are inhibited by NAC and Z-VAD pretreatments for both oral cancer cells, Ca9-22 and CAL 27.
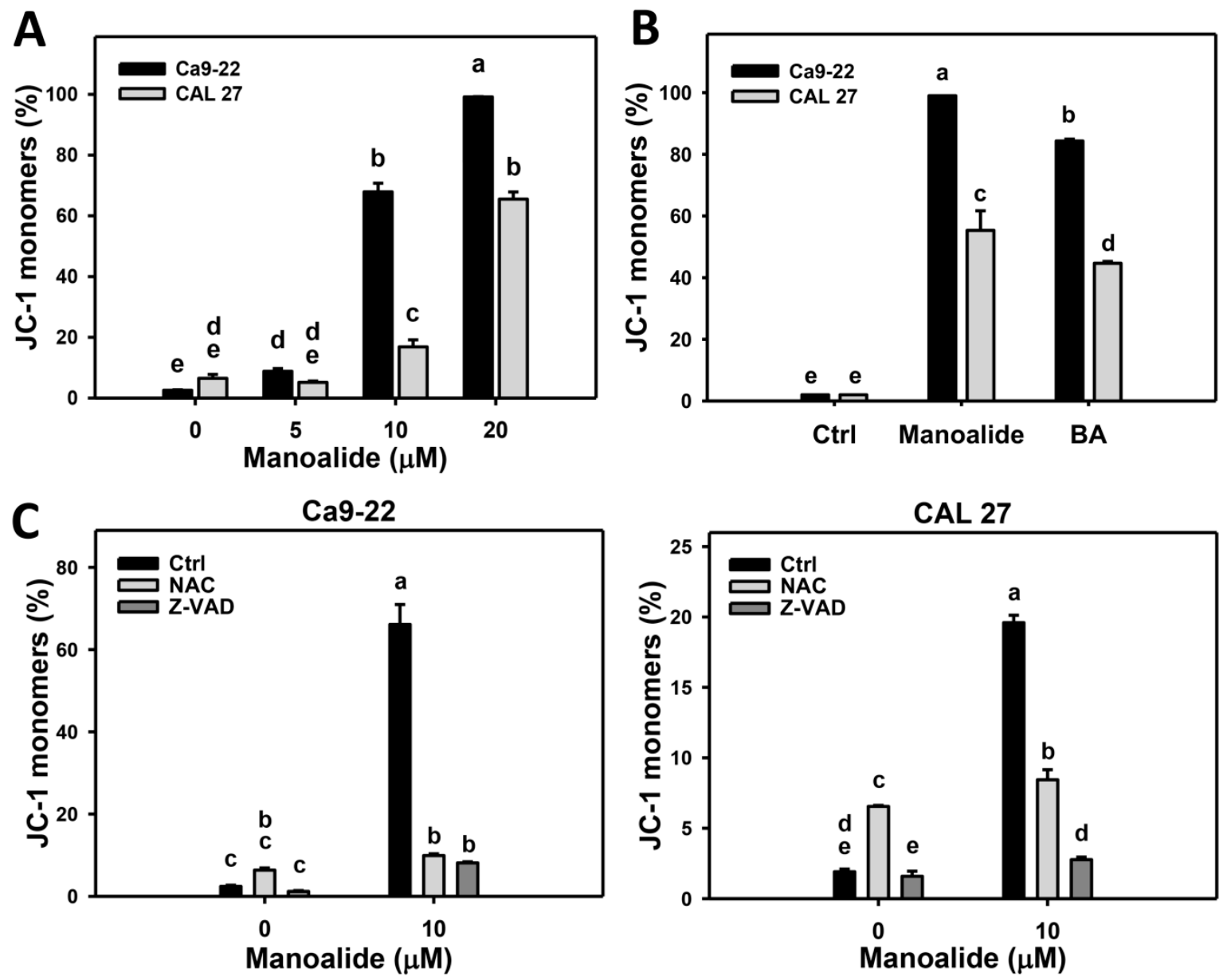

Figure 6. Change of membrane potential (MitoMP) in manoalide-treated oral cancer (Ca9-22 and CAL 27) cells. (A) Statistical results of JC-1 monomers (\%) for manoalide-treated oral cancer cells in Figure S9A. Cells were treated with different concentrations of manoalide for $24 \mathrm{~h}$. High JC-1 monomers (\%) indicates low MitoMP, i.e., the MitoMP depolarization. (B) Statistical results of positive control of low MitoMP for oral cancer cells in Figure S9B. Cells were treated with betulinic acid (BA; $25 \mu \mathrm{M}, 24 \mathrm{~h}$ ) as the positive control treatment for comparison to manoalide $(10 \mu \mathrm{M}, 24 \mathrm{~h})$. (C) Statistical results of JC-1 monomers (\%) for NAC, Z-VAD, and/or manoalide-treated oral cells in Figure S9C. Cells were pretreated with NAC $(8 \mathrm{mM}, 1 \mathrm{~h})$ or Z-VAD $(100 \mu \mathrm{M}, 2 \mathrm{~h})$ and posttreated with manoalide $(10 \mu \mathrm{M}$, 24 h). Data, means \pm SDs $(n=3)$. Data were analyzed by one-way ANOVA with Tukey HSD Post Hoc Test. Data showing no overlapping same small letters represent significant difference $(p<0.05-0.001)$.

\subsection{Flow Cytometry-Based DNA Damage Changes of Manoalide-Treated Oral Cancer Cells with or Without Pretreatments of NAC or Z-VAD}

$\gamma \mathrm{H} 2 \mathrm{AX}$ is known as a DNA double strand break marker [36]. Figure S10A shows the populations of oral cancer (Ca9-22 and CAL 27) cells shift to $\gamma \mathrm{H} 2 \mathrm{AX}(+)$ region when the concentration of manoalide increases. Figure 7A shows that the $\gamma \mathrm{H} 2 \mathrm{AX}(+)$ population is dose-responsively increased in manoalide-treated oral cancer cells. To address the role of oxidative stress and apoptosis in manoalide-induced $\gamma \mathrm{H} 2 \mathrm{AX}$, pretreatments of NAC and Z-VAD were used, and its $\gamma \mathrm{H} 2 \mathrm{AX}$ patterns are shown in Figure S10B. Figure 7B shows that the manoalide-induced $\gamma \mathrm{H} 2 \mathrm{AX}(+)(\%)$ are inhibited by NAC and Z-VAD pretreatments for both oral cancer cells, Ca9-22 and CAL 27. Moreover, the involvement of MitoSOX for manoalide-induced $\gamma \mathrm{H} 2 \mathrm{AX}$ in oral cancer cells was further examined using MitoSOX inhibitor (MitoTEMPO). Figure S10C shows the $\gamma \mathrm{H} 2 \mathrm{AX}$ patterns of MitoTEMPO pretreatment effects 
against manoalide-treated oral cancer cells. Figure 7C shows that MitoTEMPO pretreatment decreases the manoalide-induced $\gamma \mathrm{H} 2 \mathrm{AX}(+)(\%)$ for both oral cancer cells, Ca9-22 and CAL 27.
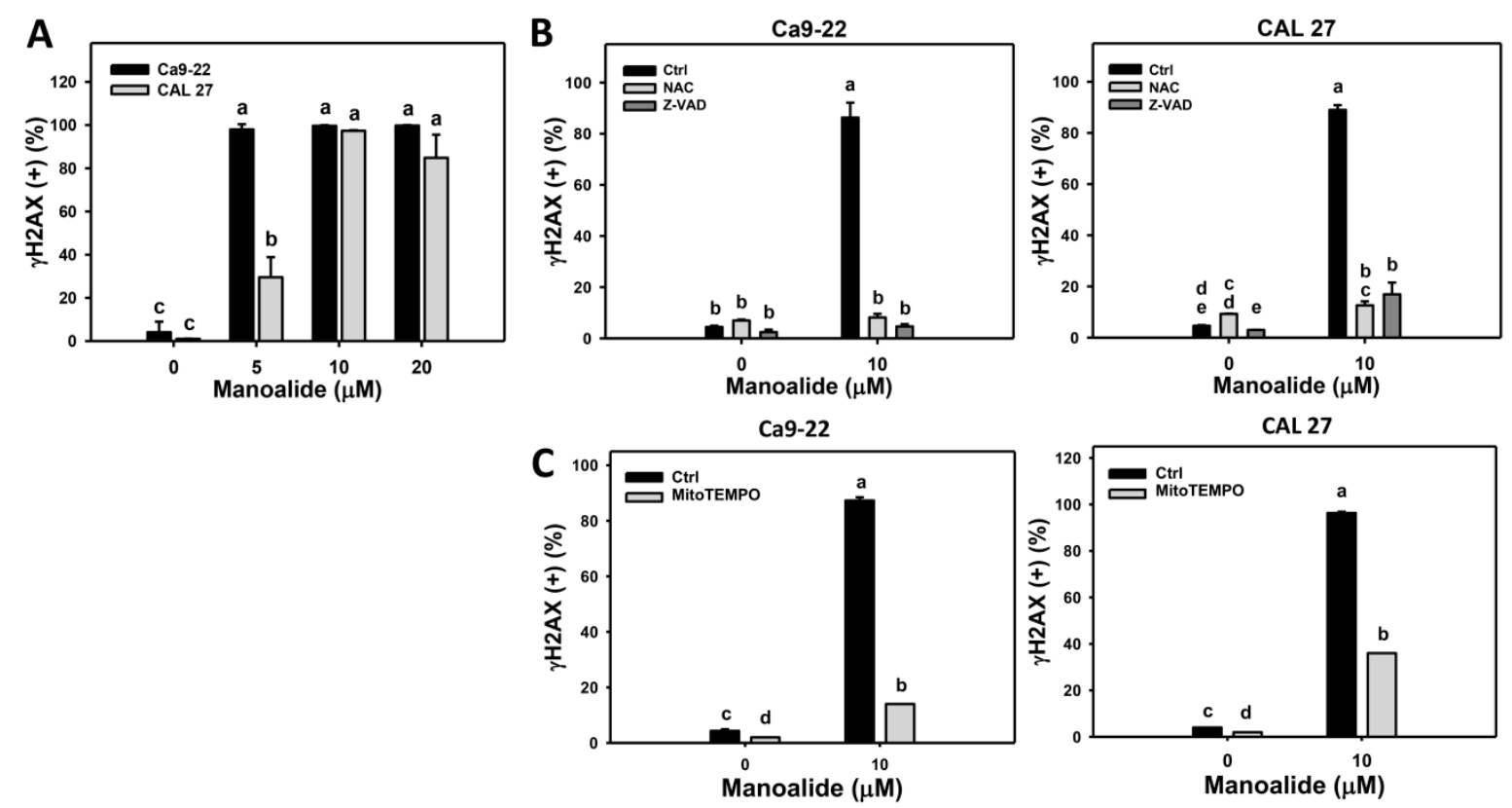

Figure 7. Change of $\gamma \mathrm{H} 2 \mathrm{AX}$ DNA damage in manoalide-treated oral cancer (Ca9-22 and CAL 27) cells. Cells were treated with the indicated concentrations of manoalide for $24 \mathrm{~h}$. (A) Statistical results of $\gamma \mathrm{H} 2 \mathrm{AX}(+)(\%)$ for manoalide-treated oral cancer cells in Figure S10A. (B) Statistical results of $\gamma \mathrm{H} 2 \mathrm{AX}(+)(\%)$ in NAC, Z-VAD, and/or manoalide-treated oral cancer cells in Figure S10B. Cells were pretreated with $8 \mathrm{mM}, 1 \mathrm{~h}$ for NAC or $100 \mu \mathrm{M}, 2 \mathrm{~h}$ for Z-VAD, and then post-incubated with $10 \mu \mathrm{M}$ of manoalide for $24 \mathrm{~h}$. (C) Statistical results of $\gamma \mathrm{H} 2 \mathrm{AX}(+)(\%)$ in MitoSOX inhibitor (MitoTEMPO) and/or manoalide-treated oral cancer cells in Figure S10C. Cells were pretreated with MitoTEMPO $(20 \mu \mathrm{M}$, $1 \mathrm{~h})$ and posttreated with manoalide $(10 \mu \mathrm{M}, 24 \mathrm{~h})$. Data were analyzed by one-way ANOVA with Tukey HSD Post Hoc Test. Data, means \pm SDs $(n=3)$. Data showing no overlapping same small letters represent significant difference $(p<0.05-0.001)$.

8-Oxo-2'-deoxyguanosine (8-oxodG) is one of the typical types of oxidative DNA damage [37]. Figure S11A shows the populations of oral cancer (Ca9-22 and CAL 27) cells shift to the 8-oxodG (+) region when the concentrations of manoalide increase, while the populations of 8-oxodG $(+)$ in normal oral (HGF-1) cells are few. Figure 8A shows that the 8-oxodG $(+)$ population is dose-responsively increased in manoalide-treated oral cancer cells; however, 8-oxodG $(+)$ was rarely appeared in normal oral (HGF-1) cells. To address the role of oxidative stress and apoptosis in manoalide-induced 8-oxodG, pretreatments of NAC and Z-VAD were used and its 8-oxodG patterns are shown in Figure S11B. Figure $8 \mathrm{~B}$ shows that the manoalide-induced 8-oxodG $(+)(\%)$ is inhibited by NAC and Z-VAD pretreatments for both oral cancer cells, Ca9-22 and CAL 27. Moreover, the involvement of MitoSOX for manoalide-induced 8-oxodG in oral cancer cells was further examined using MitoSOX inhibitor (MitoTEMPO). Figure S11C shows the 8-oxodG patterns of MitoTEMPO pretreatment effects against manoalide-treated oral cancer cells. Figure $8 \mathrm{C}$ shows that MitoTEMPO pretreatment decreases the manoalide-induced 8-oxodG (+) (\%) for both oral cancer cells, Ca9-22 and CAL 27. 

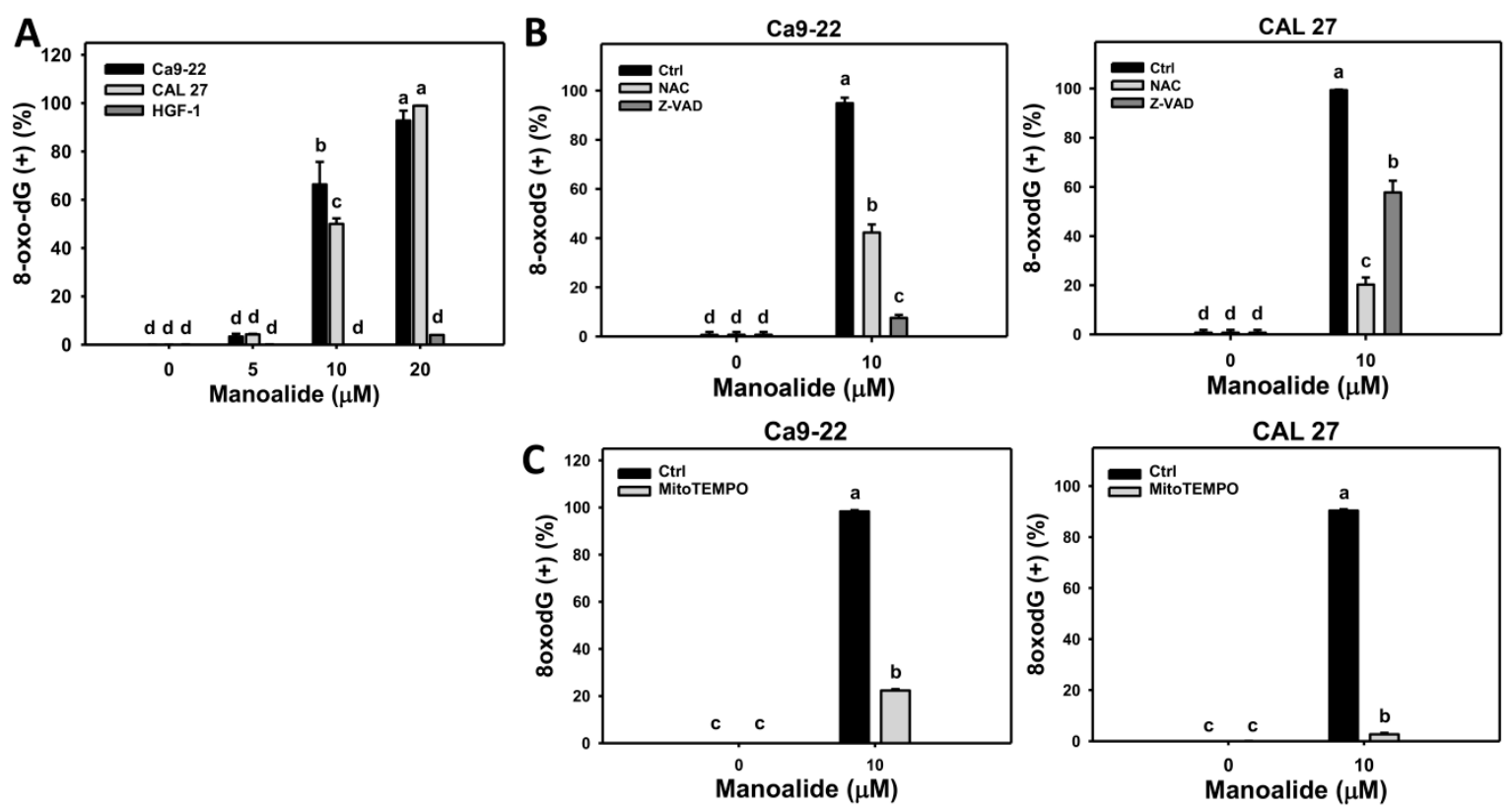

Figure 8. Change of 8-oxodG DNA damage in manoalide-treated oral cancer (Ca9-22 and CAL 27) and normal oral (HGF-1) cells. Cells were treated with the indicated concentrations of manoalide for 24 h. (A) Statistical results of 8-oxodG (+) (\%) for manoalide-treated oral cancer cells in Figure S11A. (B) Statistical results of 8-oxodG (+) (\%) in NAC, Z-VAD, and/or manoalide-treated oral cancer cells in Figure S11B. Cells were pretreated with $8 \mathrm{mM}, 1 \mathrm{~h}$ for NAC or $100 \mu \mathrm{M}, 2 \mathrm{~h}$ for Z-VAD, and then post-incubated with $10 \mu \mathrm{M}$ of manoalide for $24 \mathrm{~h}$. (C) Statistical results of 8-oxodG (+) (\%) in MitoSOX inhibitor (MitoTEMPO) and/or manoalide-treated oral cancer cells in Figure S11C. Cells were pretreated with MitoTEMPO $(20 \mu \mathrm{M}, 1 \mathrm{~h})$ and posttreated with manoalide $(10 \mu \mathrm{M}, 24 \mathrm{~h})$. Data were analyzed by one-way ANOVA with Tukey HSD Post Hoc Test. Data, means \pm SDs $(n=3)$. Data showing no overlapping same small letters represent significant difference $(p<0.05-0.001)$.

\section{Discussion}

The hypothesis that manoalide may preferentially inhibit the proliferation of oral cancer cells was validated in this study. In the following, we compare the manoalide sensitivity in different cancer cells and discuss the role of oxidative stress in preferential killing, apoptosis, and DNA damage in oral cancer cells.

\subsection{Manoalide Sensitivity in Different Cancer Cells}

Manoalide showed a cytotoxic effect against human epidermoid carcinoma $\mathrm{KB}$ cells $\left(\mathrm{IC}_{50}=\right.$ $0.725 \mu \mathrm{M})[19]$ without providing information for treatment time and methods. Moreover, KB cells were reported as misidentified; these were HeLa cells, rather than oral cancer cells [38]. In the current study, oral cancer Ca9-22, CAL 27, OECM1, OC2, and HSC3 cells, respectively, show the $\mathrm{IC}_{50}$ values of manoalide with $7.8,9.1,14.9,17.4$, and $18.5 \mu \mathrm{M}$ at $24 \mathrm{~h} \mathrm{MTS}$ assay. It is noted that the drug safety for manoalide in normal cell lines was firstly demonstrated in normal oral cells (HGF-1), which remained healthy below $25 \mu \mathrm{M}$ in a $24 \mathrm{~h}$ MTS assay. These results suggest that manoalide provides a preferentially killing effect to oral cancer cells and shows little damage to normal oral cells.

\subsection{Manoalide Induced Oxidative Stress Contributes to Preferential Killing Against Oral Cancer Cells}

Both 2,2-azinobis (3-ethyl-benzothiazoline-6-sulfonic acid) (ABTS) and hydroxyl scavenging activities of manoalide showed $\mathrm{IC}_{50}$ values for 14.3 and $18 \mu \mathrm{M}$ (Figure S12), suggesting that manoalide causes the antioxidant abilities. Recently, antioxidants were reported to display dual concentration effects [26,39], i.e., low and high concentrations, respectively, decrease and increase intracellular ROS levels. Similarly, we found that manoalide differentially induced ROS production between oral cancer 
cells and normal oral cells, i.e., manoalide induces higher ROS production in oral cancer cells than in normal oral cells (Figure 4). Moreover, manoalide also induces other types of oxidative stresses, such as MitoSOX production and MitoMP depolarization (Figures 5 and 6). Using NAC or MitoTEMPO pretreatments, oxidative stresses, such as ROS generation (Figure 4B), MitoSOX production (Figure 5C), and MitoMP depolarization (Figure 6C), as well as antiproliferation, were suppressed (Figure 1D). Therefore, the preferential killing effect of manoalide is oxidative stress-dependent in oral cancer cells. This finding also supports the rationale that ROS-modulating drugs provided preferential killing effects against several types of cancer cells $[27,40,41]$.

Manoalide displays a preferential killing against oral cancer cells with little damage to normal oral cells. Similarly, betulinic acid (BA) selectively inhibits proliferation against a number of cancer cells but not on normal cells (peripheral blood lymphoblast) [42,43], and therefore BA was chosen as a positive control. Like manoalide, BA induces ROS generation, apoptosis, and proliferation, and these effects are suppressed by NAC treatment [34]. As shown in Figures 5B and 6B, manoalide induces more MitoSOX generation and MitoMP depletion (JC-1 monomers generation) than that of BA, suggesting that manoalide is an effective oxidative stress inducer compared to BA in oral cancer cells. The anticancer effect of BA was independent on p53 mutant or wild types [42,43]. In the current study, all oral cancer cell lines harboring mutant p53 $[44,45]$ and the role of p53 status warrants detailed investigation in future.

\subsection{Manoalide Induced Oxidative stress Contributes to Apoptosis and DNA Damage Against Oral Cancer Cells}

ROS-modulating drugs commonly induce apoptosis [29,40,41,46-49]. This is indicated by NAC and Z-VAD as apoptosis inhibitors. In our study, both show the suppressing effect on manoalide-induces subG1 accumulation and apoptosis (Figures $2 \mathrm{~B}$ and $3 \mathrm{~B}$ ), suggesting that oxidative stress plays a vital role in manoalide-induced apoptosis. Additionally, we found that Cas 8 and Cas 9 inhibitors suppressed the manoalide-induced c-Cas 3 activation using flow cytometry (Figure 3E). Accordingly, the role of extrinsic and intrinsic apoptosis may be involved in manoalide-induced apoptosis, and it warrants detailed investigation in future.

It is noted that apoptosis inhibitor Z-VAD cannot completely recover the manoalide-induced antiproliferation against oral cancer cells. Half and one-third of cell viabilities for Ca9-22 and CAL 27 cells were unable to be recovered (Figure 1D). These results suggest that apoptosis cannot completely attribute to antiproliferation effects of manoalide-treated oral cancer cells. Detailed studies of the involvement of other non-apoptosis mechanisms after manoalide treatment are warranted.

Moreover, oxidative stress is a high risk factor for inducing DNA damage [41,47]. Consistently, DNA double strand breaks $(\gamma \mathrm{H} 2 \mathrm{AX})$ and oxidative DNA damage (8-oxodG) were induced in oral cancer cells upon manoalide exposure. Both $\gamma \mathrm{H} 2 \mathrm{AX}$ and 8-oxodG levels in manoalide-treated oral cancer cells were suppressed by NAC pretreatments (Figures 7B and 8B). DNA damage also has a potential to induce apoptosis [50]. Accordingly, oxidative stress may induce DNA damage and lead to apoptosis. It is noted that the manoalide-induced $\gamma \mathrm{H} 2 \mathrm{AX} / 8$-oxodG expressions (Figures 7B and $8 \mathrm{~B}$ ) and ROS production (Figure 4B) were also suppressed by Z-VAD pretreatments, suggesting that apoptosis may crosstalk to DNA damage in addition to oxidative stress.

It was reported that superoxide anion, such as MitoSOX, cannot cross the mitochondrial membrane [51]. However, we found that manoalide-induced MitoSOX generation and $\gamma \mathrm{H} 2 \mathrm{AX} / 8$-oxodG expressions (Figures 7C and 8C) were suppressed by MitoTEMPO pretreatment. Since MitoTEMPO is the mitochondria-targeted superoxide inhibitor [52], the role of MitoSOX on DNA damage is explored by MitoTEMPO pretreatment. Our finding suggests that MitoSOX may directly or indirectly induce DNA double strand breaks and oxidative DNA damage. Accordingly, the validation and mechanism of MitoSOX-induced DNA damage warrants detailed investigation in future. Therefore, both intracellular ROS and mitochondrial superoxide (MitoSOX) may contribute to the manoalide-induced DNA damage in oral cancer cells. 
The possible mechanism for preferential killing of manoalide against oral cancer cells but less damage to normal oral cells is discussed as follows. In HGF-1 cells, the ROS production is few (Figure 4A), leads to fewer annexin V-detected apoptosis (Figure 3A) and 8-oxodG DNA damage (Figure 8A) than that of oral cancer cells, and causes the oral cancer cell death but keeps normal oral cells alive.

\subsection{Potential Target Molecules of Manoalide}

Manoalide is known as an irreversible inhibitor for PLC [16] and PLA2 [53], as well as calcium channel blockers (CCBs) [17]. PLC inhibitors, such as U73122, were reported to induce apoptosis of human umbilical vein endothelial cells (HUVEC) [54]. PLA2 inhibitors, such as quercetin, were also summarized to inhibit inflammation and cancer proliferation [55]. CCBs, such as verapamil and diltiazem, have been reviewed for antiproliferation against several types of cancer cells in vitro and in vivo [56]. Accordingly, PLC, PLA2, and CCBs are the potential targets for manoalide. It warrants detailed investigation to explore the role of these potential targets between oral cancer and normal oral cells in future.

\section{Materials and Methods}

\subsection{Cell and Drug Information}

All human oral cancer cell lines (Ca9-22, CAL 27, HSC-3, OC-2, and SCC-9) and a normal oral cell line (HGF-1) were used from Health Science Research Resources Bank (HSRRB) (Osaka, Japan) and American Type Culture Collection (ATCC; Manassas, VA, USA) except for OECM1 [57], a generous gift from Dr. Wan-Chi Tsai (Kaohsiung Medical University, Taiwan). Cells were cultured in $5 \% \mathrm{CO}_{2}$ at 37 ${ }^{\circ} \mathrm{C}$ with humidity and maintained by regular formula (Gibco, Grand Island, NY, USA) with $10 \%$ fetal bovine serum as previously described [49].

Manoalide (CAYMAN CHEMICAL, Ann Arbor, MI, USA) was dissolved in dimethyl sulfoxide (DMSO) for treatment. A ROS scavenger $N$-acetylcysteine (NAC) [58] (Sigma-Aldrich; St. Louis, MO, USA) was dissolved in double distilled water. The mitochondrial superoxide inhibitor MitoTEMPO [59] (Cayman Chemical, Ann Arbor, MI, USA), panapoptosis inhibitor Z-VAD-FMK [60], Cas 8 inhibitor Z-IETD-FMK, and Cas 9 inhibitor Z-LEHD-FMK (Selleckchem.com; Houston, TX, USA) was dissolved in DMSO. All experiments contain the same concentration of DMSO.

\subsection{Cell Viability Assay}

After drug treatment, the mitochondrial activity-based cell viability was determined by MTS assay (CellTiter 96 Aqueous One Solution, Promega, Madison, WI, USA) at 24 h [61], and the 3D microtissue spheroids viability of oral cancer cells was measured by the CellTiter-Glo ${ }^{\circledR}$ 3D Cell Viability Assay (Promega, Madison, WI, USA) coupling with ATP level detection at $72 \mathrm{~h}$ [62].

\subsection{Cell Cycle Assay}

7AAD (Biotium, Inc., Hayward, CA, USA), a DNA dye, was applied to cell cycle analysis [63]. Briefly, drugs-treated cells were stained with $7 \mathrm{AAD}\left(1 \mu \mathrm{g} / \mathrm{mL}, 37^{\circ} \mathrm{C}, 30 \mathrm{~min}\right)$. Finally, the cell cycle change was analyzed by Accuri ${ }^{\mathrm{TM}}$ C6 flow cytometry (Becton-Dickinson, Mansfield, MA, USA).

\subsection{Annexin V/7AAD Assay for Apoptosis}

Annexin V (Strong Biotech Corporation, Taipei, Taiwan) coupled with 7AAD was used for apoptosis analysis [64]. Briefly, drugs-treated cells were incubated with the mixture of annexin V-fluorescein isothiocyanate (FITC) $(10 \mu \mathrm{g} / \mathrm{mL})$ and 7AAD $(1 \mu \mathrm{g} / \mathrm{mL})$ at $37^{\circ} \mathrm{C}$ for $30 \mathrm{~min}$. Finally, the apoptosis expression was analyzed by Accuri ${ }^{\mathrm{TM}} \mathrm{C} 6$ flow cytometry. 


\subsection{Western Blotting and c-Cas 3-Based Flow Cytometry for Apoptosis}

Detailed steps of western blotting were previously described [60]. Briefly, the primary apoptosis antibodies (diluted 1:1000) including cleaved caspase-3 (c-Cas 3) rabbit mAb (Cell Signaling Technology, Inc., Danvers, MA, USA) were used. The internal control primary antibody (diluted 1:5000) was mAb- $\beta$-actin (Sigma-Aldrich, St. Louis, MO, USA). Following secondary antibody treatment, these protein signals were detected using enhanced chemiluminescence (ECL) substrate (WesternBright ${ }^{\mathrm{TM}}$ ECL HRP, Advansta, Menlo Park, CA, USA).

For c-Cas 3-based flow cytometry, cells were fixed with 70\% ethanol, washed, and incubated with $1 \mu \mathrm{g} / \mathrm{mL}$ of c-Cas 3 (Asp175) rabbit mAb (Cell Signaling Technology) at $4{ }^{\circ} \mathrm{C}$ for overnight. After washing, cells were incubated with a secondary polyclonal antibody conjugated with Alexa Fluor 488 (ThermoFisher Scientific, San Jose, CA, USA) at room temperature for $1 \mathrm{~h}$. Finally, the c-Cas 3 expression was analyzed by Accuri ${ }^{\mathrm{TM}} \mathrm{C} 6$ flow cytometry. Cas 8 inhibitor Z-IETD-FMK $(100 \mu \mathrm{M}, 2 \mathrm{~h})$ or Cas 9 inhibitor Z-LEHD-FMK $(100 \mu \mathrm{M}, 2 \mathrm{~h})$ were applied to examine the involvement of Cas 8 and Cas 9 in apoptosis.

\subsection{ROS Assay}

DCFH-DA (Sigma-Aldrich; St. Louis, MO, USA) was used for ROS detecting dye [32]. Briefly, drugs-treated cells were incubated with DCFH-DA reagent $\left(10 \mu \mathrm{M}, 37^{\circ} \mathrm{C}, 30 \mathrm{~min}\right)$. Finally, the ROS level was analyzed by Accuri ${ }^{\mathrm{TM}} \mathrm{C} 6$ flow cytometry.

\subsection{MitoSOX Assay}

MitoSOX ${ }^{\mathrm{TM}}$ Red (Molecular Probes, Invitrogen, Eugene, OR, USA) was used as mitochondrial superoxide detecting dye [33]. Briefly, drugs-treated cells were incubated with MitoSOX reagent [48,49] $\left(5 \mu \mathrm{M}, 37^{\circ} \mathrm{C}, 30 \mathrm{~min}\right)$. Finally, the MitoSOX level was analyzed by Accuri ${ }^{\mathrm{TM}} \mathrm{C} 6$ flow cytometry.

\subsection{MitoMP Assay}

JC-1 (Merckmillipore) was used to detect mitochondrial membrane potential (MitoMP). JC-1 aggregate form generated red fluorescence indicating the normal function for MitoMP [35]. In contrast, JC-1 monomer form generated green fluorescence, indicating the dysfunction for MitoMP. Therefore, green fluorescent signals were counted as the decrease of MitoMP. Briefly, drugs-treated cells were treated with JC- $1\left(0.1 \mathrm{mM}, 37^{\circ} \mathrm{C}, 30 \mathrm{~min}\right)$. Finally, the MitoMP level was analyzed by Accuri ${ }^{\mathrm{TM}}$ C6 flow cytometry.

\section{9. $\gamma H 2 A X$ Assay}

DNA double strand break marker $(\gamma \mathrm{H} 2 \mathrm{AX})$ was detected by antibody-based flow cytometry [40]. Briefly, drugs-treated cells were incubated with mouse primary antibody p-Histone H2A.X (Ser 139) (Santa Cruz Biotechnology, Santa Cruz, CA, USA) (1:100 dilution, $4{ }^{\circ} \mathrm{C}, 1 \mathrm{~h}$ ) and washed for incubation with the secondary antibody-labeled with Alexa Fluor 488 (Cell Signaling Technology) (1:10000 dilution, $\left.4{ }^{\circ} \mathrm{C}, 1 \mathrm{~h}\right)$. Finally, the $\gamma \mathrm{H} 2 \mathrm{AX}$ level was analyzed by Accuri ${ }^{\mathrm{TM}} \mathrm{C} 6$ flow cytometry.

\subsection{8-oxodG Assay}

8-oxodG was detected by antibody-based flow cytometry using a fluorometric OxyDNA assay kit (\#500095; EMD Millipore, Darmstadt, Germany) [65,66]. Briefly, drugs-treated cells were incubated in antibody-labeled with FITC ( $10 \times$ dilution, $\left.4{ }^{\circ} \mathrm{C}, 1 \mathrm{~h}\right)$. Finally, the 8-oxodG level was analyzed by Accuri ${ }^{\mathrm{TM}}$ C6 flow cytometry. 


\subsection{Statistical Analysis}

Using JMP ${ }^{\circledR} 12$ software, the significance of multiple comparisons between different treatments were analyzed by one-way ANOVA with Tukey HSD Post Hoc Test. Data showing no overlapping same small letters represent significant difference.

\section{Conclusions}

This study confirmed the hypothesis that manoalide may preferentially inhibit the proliferation of oral cancer cells. We found several types of results supporting that oxidative stresses were induced by manoalide. The oxidative stresses, such as intracellular ROS and MitoSOX/MitoMP, were also involved in manoalide-induced apoptosis and DNA damages in oral cancer cells. Finally, these mechanisms may contribute to preferentially inhibit the proliferation of oral cancer cells (Figure 9). Taken together, this study firstly shows that manoalide preferentially kills oral cancer cells without cytotoxic side effects to normal oral cells.

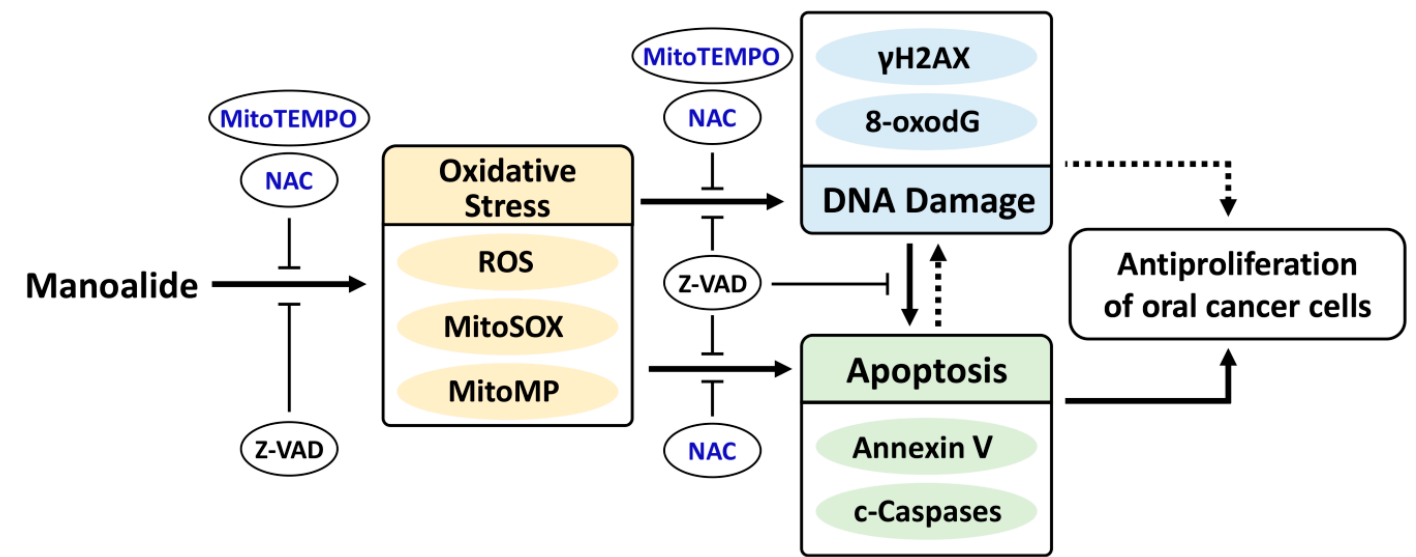

Figure 9. Expected mechanism of manoalide-induced preferential antiproliferation on oral cancer cells. Manoalide may preferentially kill oral cancer cells by inducing oxidative stress, such as ROS and MitoSOX productions, as well as MitoMP depolarization. These oxidative stresses may induce DNA double strand break damage and oxidative DNA 8-oxodG DNA damage. DNA damage may induce apoptosis and inhibit proliferation [67]. Finally, these oxidative stress and DNA damage changes cooperate to induce apoptosis [50] and lead to preferential antiproliferation of oral cancer cells. Additionally, apoptosis may also regulate DNA damage and oxidative stress. Solid lines (arrow and T) indicate the activating and inhibiting results from this study, whereas dashed lines indicate the mechanism is supported by literature.

Supplementary Materials: The following are available online at http://www.mdpi.com/2072-6694/11/9/1303/s1, Figure S1: 3D spheroid formation and cell morphology of oral cancer cells after manoalide treatment and its NAC/Z-VAD effects, Figure S2: Cell cycle changes of manoalide-treated oral cancer (Ca9-22 and CAL 27) cells, Figure S3: Apoptosis changes in manoalide-treated oral cancer (Ca9-22 and CAL 27) cells and normal oral (HGF-1) cells, Figure S4: Western blotting for procaspase 3 and cleaved caspase 3 (c-Cas 3) in manoalide-treated oral cancer (Ca9-22 and CAL 27) cells, Figure S5: Raw data for western blotting of cleaved caspase 3 (c-Cas 3) with or without NAC and Z-VAD pretreatment in manoalide-treated oral cancer (Ca9-22 and CAL 27) cells, Figure S6: Fluorescence staining of cleaved caspases 8 and 9 (c-Cas 8/9) and the effects of Cas 8/9 inhibitors on c-Cas 3-based flow cytometry, Figure S7: ROS changes in manoalide-treated oral cancer (Ca9-22 and CAL 27) and normal oral (HGF-1) cells, Figure S8: Change of MitoSOX production in manoalide-treated oral cancer (Ca9-22 and CAL 27) cells, Figure S9: Change of MitoMP in manoalide-treated oral cancer (Ca9-22 and CAL 27) cells, Figure S10: Change of $\gamma \mathrm{H} 2 \mathrm{AX}$ DNA damage in manoalide-treated oral cancer (Ca9-22 and CAL 27) cells, Figure S11: Change of 8-oxodG DNA damage in manoalide-treated oral cancer (Ca9-22 and CAL 27) cells, and Figure S12: ABTS and hydroxyl scavenging assays for manoalide.

Author Contributions: H.-R.W. and H.-W.C. contributed to original draft preparation. H.-R.W. performed the cytotoxicity assays, flow cytometry, and western blotting. J.-Y.T., Y.-Y.W., A.A.F., C.-Y.Y., and S.-S.F.Y. contributed to methodology, data analysis, and statistics. H.-W.H. and H.-W.C. designed the whole experiment and improved the manuscript. 
Funding: This work was partly supported by funds of the Ministry of Science and Technology (MOST 108-2320-B-037-015-MY3, MOST 108-2314-B-037-020, MOST 108-2314-B-384-002), the National Sun Yat-sen University-KMU Joint Research Project (\#NSYSUKMU 108-P001), the Chimei-KMU jointed project (108CM-KMU-11), the Kaohsiung Medical University Hospital (KMUH107-7R74), the Kaohsiung Medical University Research Center (KMU-TC108A04), and the Health and welfare surcharge of tobacco products, the Ministry of Health and Welfare, Taiwan, Republic of China (MOHW 108-TDU-B-212-124016).

Acknowledgments: The authors thank Hans-Uwe Dahms for editing the manuscript, the Center for Research Resources and Development of Kaohsiung Medical University for providing the service of LSRII system, and Sheng-Chieh Wang for ABTS/hydroxyl scavenging testing.

Conflicts of Interest: The authors declare no conflict of interest. The funders had no role in the design of the study; in the collection, analyses, or interpretation of data; in the writing of the manuscript, or in the decision to publish the results.

\section{References}

1. Montero, P.H.; Patel, S.G. Cancer of the oral cavity. Surg. Oncol. Clin. N. Am. 2015, 24, 491-508. [CrossRef] [PubMed]

2. Ko, Y.C.; Huang, Y.L.; Lee, C.H.; Chen, M.J.; Lin, L.M.; Tsai, C.C. Betel quid chewing, cigarette smoking and alcohol consumption related to oral cancer in Taiwan. J. Oral Pathol. Med. 1995, 24, 450-453. [CrossRef] [PubMed]

3. Petersen, P.E. Oral cancer prevention and control-The approach of the World Health Organization. Oral Oncol. 2009, 45, 454-460. [CrossRef] [PubMed]

4. Silverman, S., Jr. Oral cancer: Complications of therapy. Oral Surg. Oral Med. Oral Pathol. Oral Radiol. Endod. 1999, 88, 122-126. [CrossRef]

5. Singh, R.; Sharma, M.; Joshi, P.; Rawat, D.S. Clinical status of anti-cancer agents derived from marine sources. Anticancer Agents Med. Chem. 2008, 8, 603-617. [CrossRef] [PubMed]

6. Sithranga Boopathy, N.; Kathiresan, K. Anticancer drugs from marine flora: An overview. J. Oncol. 2010, 2010, 214186. [CrossRef]

7. Farooqi, A.A.; Fayyaz, S.; Hou, M.F.; Li, K.T.; Tang, J.Y.; Chang, H.W. Reactive oxygen species and autophagy modulation in non-marine drugs and marine drugs. Mar. Drugs 2014, 12, 5408-5424. [CrossRef]

8. Lee, M.G.; Liu, Y.C.; Lee, Y.L.; El-Shazly, M.; Lai, K.H.; Shih, S.P.; Ke, S.C.; Hong, M.C.; Du, Y.C.; Yang, J.C.; et al. Heteronemin, a marine sesterterpenoid-type metabolite, induces apoptosis in prostate LNcap cells via oxidative and ER stress combined with the inhibition of topoisomerase II and Hsp90. Mar. Drugs 2018, 16, 204. [CrossRef]

9. Mehbub, M.F.; Lei, J.; Franco, C.; Zhang, W. Marine sponge derived natural products between 2001 and 2010: Trends and opportunities for discovery of bioactives. Mar. Drugs 2014, 12, 4539-4577. [CrossRef]

10. Mehbub, M.F.; Perkins, M.V.; Zhang, W.; Franco, C.M.M. New marine natural products from sponges (Porifera) of the order Dictyoceratida (2001 to 2012); A promising source for drug discovery, exploration and future prospects. Biotechnol. Adv. 2016, 34, 473-491. [CrossRef]

11. Calcabrini, C.; Catanzaro, E.; Bishayee, A.; Turrini, E.; Fimognari, C. Marine sponge natural products with anticancer potential: An updated review. Mar. Drugs 2017, 15, 310. [CrossRef] [PubMed]

12. Perdicaris, S.; Vlachogianni, T.; Valavanidis, A. Bioactive natural substances from marine sponges: New developments and prospects for future pharmaceuticals. Nat. Prod. Chem. Res. 2013, 1, 114. [CrossRef]

13. de Silva, E.D.; Scheuer, P.J. Manoalide, an antibiotic sesterterpenoid from the marine sponge Luffariella variabilis (polejaeff). Tetrahedron Lett. 1980, 21, 1611-1614. [CrossRef]

14. Soriente, A.; De Rosa, M.M.; Scettri, A.; Sodano, G.; Terencio, M.C.; Paya, M.; Alcaraz, M.J. Manoalide. Curr. Med. Chem. 1999, 6, 415-431. [PubMed]

15. Muallem, S.; Loessberg, P.; Sachs, G.; Wheeler, L.A. Agonist-sensitive and -insensitive intracellular Ca ${ }^{2+}$ pools. Separate $\mathrm{Ca}^{2+}$-releasing mechanisms revealed by manoalide and benzohydroquinone. Biochem. J. 1991, 279, 367-375. [CrossRef] [PubMed]

16. Bennett, C.F.; Mong, S.; Wu, H.L.; Clark, M.A.; Wheeler, L.; Crooke, S.T. Inhibition of phosphoinositide-specific phospholipase C by manoalide. Mol. Pharmacol. 1987, 32, 587-593. [PubMed]

17. Wheeler, L.A.; Sachs, G.; De Vries, G.; Goodrum, D.; Woldemussie, E.; Muallem, S. Manoalide, a natural sesterterpenoid that inhibits calcium channels. J. Biol. Chem. 1987, 262, 6531-6538. [PubMed] 
18. Kijjoa, A.; Sawangwong, P. Drugs and cosmetics from the sea. Mar. Drugs 2004, 2, 73-82. [CrossRef]

19. Kobayashi, J.; Zeng, C.M.; Ishibashi, M.; Sasaki, T. Luffariolides F and G, new manoalide derivatives from the Okinawan marine sponge Luffariella sp. J. Nat. Prod. 1993, 56, 436-439. [CrossRef]

20. Thambidurai, Y.; D, S.; SKM, H.; T, A.K. Free radical scavenging activity of marine sponges collected from Kovalam, Chennai. Asian J. Pharm. Clin. Res. 2017, 10, 321. [CrossRef]

21. Utkina, N.K. Antioxidant activity of zyzzyanones and makaluvamines from the marine sponge Zyzzya fuliginosa. Nat. Prod. Commun. 2013, 8, 1551-1552. [CrossRef] [PubMed]

22. Chairman, K.; Singh, A.J.A.R.; Alagumuthu, G. Cytotoxic and antioxidant activity of selected marine sponges. Asian Pac. J. Trop. Dis. 2012, 2, 234-238. [CrossRef]

23. Abdillah, S.; Nurhayati, A.P.D.; Nurhatika, S.; Setiawan, E.; Heffen, W.L. Cytotoxic and antioxidant activities of marine sponge diversity at Pecaron Bay Pasir Putih Situbondo East Java, Indonesia. J. Pharm. Res. 2013, 6, 685-689. [CrossRef]

24. Rivera, A.P.; Uy, M.M. In vitro antioxidant and cytotoxic activities of some marine sponges collected off Misamis Oriental Coast, Philippines. E-J. Chem. 2012, 9, 354-358. [CrossRef]

25. de Carvalho, D.D.; Sadok, A.; Bourgarel-Rey, V.; Gattacceca, F.; Penel, C.; Lehmann, M.; Kovacic, H. Nox1 downstream of 12-lipoxygenase controls cell proliferation but not cell spreading of colon cancer cells. Int. J. Cancer 2008, 122, 1757-1764. [CrossRef] [PubMed]

26. Bouayed, J.; Bohn, T. Exogenous antioxidants—Double-edged swords in cellular redox state: Health beneficial effects at physiologic doses versus deleterious effects at high doses. Oxid. Med. Cell Longev. 2010, 3, $228-237$. [CrossRef] [PubMed]

27. Suzuki-Karasaki, Y.; Suzuki-Karasaki, M.; Uchida, M.; Ochiai, T. Depolarization controls TRAIL-sensitization and tumor-selective killing of cancer cells: Crosstalk with ROS. Front. Oncol. 2014, 4, 128. [CrossRef] [PubMed]

28. Hseu, Y.C.; Lee, M.S.; Wu, C.R.; Cho, H.J.; Lin, K.Y.; Lai, G.H.; Wang, S.Y.; Kuo, Y.H.; Kumar, K.J.; Yang, H.L. The chalcone flavokawain B induces G2/M cell-cycle arrest and apoptosis in human oral carcinoma HSC-3 cells through the intracellular ROS generation and downregulation of the Akt/p38 MAPK signaling pathway. J. Agric. Food Chem. 2012, 60, 2385-2397. [CrossRef] [PubMed]

29. Shih, H.C.; El-Shazly, M.; Juan, Y.S.; Chang, C.Y.; Su, J.H.; Chen, Y.C.; Shih, S.P.; Chen, H.M.; Wu, Y.C.; Lu, M.C. Cracking the cytotoxicity code: Apoptotic induction of 10-acetylirciformonin B is mediated through ROS generation and mitochondrial dysfunction. Mar. Drugs 2014, 12, 3072-3090. [CrossRef]

30. Tang, J.Y.; Wu, C.Y.; Shu, C.W.; Wang, S.C.; Chang, M.Y.; Chang, H.W. A novel sulfonyl chromen-4-ones (CHW09) preferentially kills oral cancer cells showing apoptosis, oxidative stress, and DNA damage. Environ. Toxicol. 2018, 33, 1195-1203. [CrossRef]

31. Nakagawa, Y.; Takahashi, A.; Kajihara, A.; Yamakawa, N.; Imai, Y.; Ota, I.; Okamoto, N.; Mori, E.; Noda, T.; Furusawa, Y.; et al. Depression of p53-independent Akt survival signals in human oral cancer cells bearing mutated p53 gene after exposure to high-LET radiation. Biochem. Biophys. Res. Commun. 2012, 423, 654-660. [CrossRef] [PubMed]

32. Yeh, C.C.; Yang, J.I.; Lee, J.C.; Tseng, C.N.; Chan, Y.C.; Hseu, Y.C.; Tang, J.Y.; Chuang, L.Y.; Huang, H.W.; Chang, F.R.; et al. Anti-proliferative effect of methanolic extract of Gracilaria tenuistipitata on oral cancer cells involves apoptosis, DNA damage, and oxidative stress. BMC Complement. Altern. Med. 2012, $12,142$. [CrossRef] [PubMed]

33. Mukhopadhyay, P.; Rajesh, M.; Yoshihiro, K.; Hasko, G.; Pacher, P. Simple quantitative detection of mitochondrial superoxide production in live cells. Biochem. Biophys. Res. Commun. 2007, 358, $203-208$. [CrossRef] [PubMed]

34. Shen, H.; Liu, L.; Yang, Y.; Xun, W.; Wei, K.; Zeng, G. Betulinic acid inhibits cell proliferation in human oral squamous cell carcinoma via modulating ROS-regulated p53 signaling. Oncol. Res. 2017, 25, 1141-1152. [CrossRef] [PubMed]

35. Jin, C.Y.; Park, C.; Lee, J.H.; Chung, K.T.; Kwon, T.K.; Kim, G.Y.; Choi, B.T.; Choi, Y.H. Naringenin-induced apoptosis is attenuated by Bcl-2 but restored by the small molecule Bcl-2 inhibitor, HA 14-1, in human leukemia U937 cells. Toxicol. In Vitro 2009, 23, 259-265. [CrossRef] [PubMed]

36. Kuo, L.J.; Yang, L.X. Gamma-H2AX-A novel biomarker for DNA double-strand breaks. In Vivo 2008, 22, 305-309. [PubMed] 
37. Roszkowski, K.; Jozwicki, W.; Blaszczyk, P.; Mucha-Malecka, A.; Siomek, A. Oxidative damage DNA: 8-oxoGua and 8-oxodG as molecular markers of cancer. Med. Sci. Monit. 2011, 17, CR329-CR333. [CrossRef]

38. Vaughan, L.; Glanzel, W.; Korch, C.; Capes-Davis, A. Widespread use of misidentified cell line KB (HeLa): Incorrect attribution and its impact revealed through mining the scientific literature. Cancer Res. 2017, 77, 2784-2788. [CrossRef]

39. Yen, C.Y.; Hou, M.F.; Yang, Z.W.; Tang, J.Y.; Li, K.T.; Huang, H.W.; Huang, Y.H.; Lee, S.Y.; Fu, T.F.; Hsieh, C.Y.; et al. Concentration effects of grape seed extracts in anti-oral cancer cells involving differential apoptosis, oxidative stress, and DNA damage. BMC Complement. Altern. Med. 2015, 15, 94. [CrossRef]

40. Chiu, C.C.; Haung, J.W.; Chang, F.R.; Huang, K.J.; Huang, H.M.; Huang, H.W.; Chou, C.K.; Wu, Y.C.; Chang, H.W. Golden berry-derived 4beta-hydroxywithanolide E for selectively killing oral cancer cells by generating ROS, DNA damage, and apoptotic pathways. PLoS ONE 2013, 8, e64739. [CrossRef]

41. Chang, H.W.; Li, R.N.; Wang, H.R.; Liu, J.R.; Tang, J.Y.; Huang, H.W.; Chan, Y.H.; Yen, C.Y. Withaferin A induces oxidative stress-mediated apoptosis and DNA damage in oral cancer cells. Front. Physiol. 2017, 8, 634. [CrossRef] [PubMed]

42. Zuco, V.; Supino, R.; Righetti, S.C.; Cleris, L.; Marchesi, E.; Gambacorti-Passerini, C.; Formelli, F. Selective cytotoxicity of betulinic acid on tumor cell lines, but not on normal cells. Cancer Lett. 2002, 175, 17-25. [CrossRef]

43. Shankar, E.; Zhang, A.; Franco, D.; Gupta, S. Betulinic acid-mediated apoptosis in human prostate cancer cells involves p53 and nuclear factor-kappa B (NF-kappaB) pathways. Molecules 2017, 22, 264. [CrossRef]

44. Lin, S.C.; Liu, C.J.; Chiu, C.P.; Chang, S.M.; Lu, S.Y.; Chen, Y.J. Establishment of OC3 oral carcinoma cell line and identification of NF-kappa B activation responses to areca nut extract. J. Oral Pathol. Med. 2004, 33, 79-86. [CrossRef] [PubMed]

45. Hamroun, D.; Kato, S.; Ishioka, C.; Claustres, M.; Beroud, C.; Soussi, T. The UMD TP53 database and website: Update and revisions. Hum. Mutat. 2006, 27, 14-20. [CrossRef] [PubMed]

46. Huang, C.H.; Huang, Z.W.; Ho, F.M.; Chan, W.H. Berberine impairs embryonic development in vitro and in vivo through oxidative stress-mediated apoptotic processes. Environ. Toxicol. 2018, 33, 280-294. [CrossRef] [PubMed]

47. Hung, J.H.; Chen, C.Y.; Omar, H.A.; Huang, K.Y.; Tsao, C.C.; Chiu, C.C.; Chen, Y.L.; Chen, P.H.; Teng, Y.N. Reactive oxygen species mediate Terbufos-induced apoptosis in mouse testicular cell lines via the modulation of cell cycle and pro-apoptotic proteins. Environ. Toxicol. 2016, 31, 1888-1898. [CrossRef] [PubMed]

48. Chang, Y.T.; Huang, C.Y.; Tang, J.Y.; Liaw, C.C.; Li, R.N.; Liu, J.R.; Sheu, J.H.; Chang, H.W. Reactive oxygen species mediate soft corals-derived sinuleptolide-induced antiproliferation and DNA damage in oral cancer cells. Onco Targets Ther. 2017, 10, 3289-3297. [CrossRef]

49. Chang, Y.T.; Huang, C.Y.; Li, K.T.; Li, R.N.; Liaw, C.C.; Wu, S.H.; Liu, J.R.; Sheu, J.H.; Chang, H.W. Sinuleptolide inhibits proliferation of oral cancer Ca9-22 cells involving apoptosis, oxidative stress, and DNA damage. Arch. Oral Biol. 2016, 66, 147-154. [CrossRef]

50. Norbury, C.J.; Zhivotovsky, B. DNA damage-induced apoptosis. Oncogene 2004, 23, 2797-2808. [CrossRef]

51. Inoue, M.; Sato, E.F.; Nishikawa, M.; Park, A.M.; Kira, Y.; Imada, I.; Utsumi, K. Mitochondrial generation of reactive oxygen species and its role in aerobic life. Curr. Med. Chem. 2003, 10, 2495-2505. [CrossRef] [PubMed]

52. Liang, H.L.; Sedlic, F.; Bosnjak, Z.; Nilakantan, V. SOD1 and MitoTEMPO partially prevent mitochondrial permeability transition pore opening, necrosis, and mitochondrial apoptosis after ATP depletion recovery. Free Radic. Biol. Med. 2010, 49, 1550-1560. [CrossRef] [PubMed]

53. Lombardo, D.; Dennis, E.A. Cobra venom phospholipase A2 inhibition by manoalide. A novel type of phospholipase inhibitor. J. Biol. Chem. 1985, 260, 7234-7240. [PubMed]

54. Miao, J.Y.; Kaji, K.; Hayashi, H.; Araki, S. Inhibitors of phospholipase promote apoptosis of human endothelial cells. J. Biochem. 1997, 121, 612-618. [CrossRef] [PubMed]

55. Yarla, N.; Satyakumar, K.; Srinivasu, D.; DSVGK K, A.G.; Dharmapuri, G.; Putta, G.; Jagarlapoodi, S.; Bheeram, V.; Sadu, S.; Duddukuri, G. Phospholipase A2: A potential therapeutic target in inflammation and cancer (In silico, In vitro, In vivo and clinical approach). J. Cancer Sci. Ther. 2015, 7, 8.

56. Mason, R.P. Calcium channel blockers, apoptosis and cancer: Is there a biologic relationship? J. Am. Coll. Cardiol. 1999, 34, 1857-1866. [CrossRef] 
57. Yang, C.Y.; Meng, C.L. Regulation of PG synthase by EGF and PDGF in human oral, breast, stomach, and fibrosarcoma cancer cell lines. J. Dent. Res. 1994, 73, 1407-1415. [CrossRef] [PubMed]

58. Huang, C.H.; Yeh, J.M.; Chan, W.H. Hazardous impacts of silver nanoparticles on mouse oocyte maturation and fertilization and fetal development through induction of apoptotic processes. Environ. Toxicol. 2018, 33, 1039-1049. [CrossRef]

59. Wang, T.S.; Lin, C.P.; Chen, Y.P.; Chao, M.R.; Li, C.C.; Liu, K.L. CYP450-mediated mitochondrial ROS production involved in arecoline N-oxide-induced oxidative damage in liver cell lines. Environ. Toxicol. 2018, 33, 1029-1038. [CrossRef]

60. Chen, C.Y.; Yen, C.Y.; Wang, H.R.; Yang, H.P.; Tang, J.Y.; Huang, H.W.; Hsu, S.H.; Chang, H.W. Tenuifolide B from Cinnamomum tenuifolium stem selectively inhibits proliferation of oral cancer cells via apoptosis, ROS generation, mitochondrial depolarization, and DNA damage. Toxins (Basel) 2016, 8, 319. [CrossRef]

61. Yeh, C.C.; Tseng, C.N.; Yang, J.I.; Huang, H.W.; Fang, Y.; Tang, J.Y.; Chang, F.R.; Chang, H.W. Antiproliferation and induction of apoptosis in Ca9-22 oral cancer cells by ethanolic extract of Gracilaria tenuistipitata. Molecules 2012, 17, 10916-10927. [CrossRef] [PubMed]

62. Liu, P.F.; Chang, H.W.; Cheng, J.S.; Lee, H.P.; Yen, C.Y.; Tsai, W.L.; Cheng, J.T.; Li, Y.J.; Huang, W.C.; Lee, C.H.; et al. Map1lc3b and Sqstm1 modulated autophagy for tumorigenesis and prognosis in certain subsites of oral squamous cell carcinoma. J. Clin. Med. 2018, 7, 478. [CrossRef] [PubMed]

63. Vignon, C.; Debeissat, C.; Georget, M.T.; Bouscary, D.; Gyan, E.; Rosset, P.; Herault, O. Flow cytometric quantification of all phases of the cell cycle and apoptosis in a two-color fluorescence plot. PLOS ONE 2013, 8, e68425. [CrossRef] [PubMed]

64. Huang, H.W.; Tang, J.Y.; Ou-Yang, F.; Wang, H.R.; Guan, P.Y.; Huang, C.Y.; Chen, C.Y.; Hou, M.F.; Sheu, J.H.; Chang, H.W. Sinularin selectively kills breast cancer cells showing G2/M arrest, apoptosis, and oxidative DNA damage. Molecules 2018, 23, 849. [CrossRef] [PubMed]

65. Bartkova, J.; Hamerlik, P.; Stockhausen, M.T.; Ehrmann, J.; Hlobilkova, A.; Laursen, H.; Kalita, O.; Kolar, Z.; Poulsen, H.S.; Broholm, H.; et al. Replication stress and oxidative damage contribute to aberrant constitutive activation of DNA damage signalling in human gliomas. Oncogene 2010, 29, 5095-5102. [CrossRef] [PubMed]

66. Nagy, S.; Kakasi, B.; Bercsenyi, M. Flow cytometric detection of oxidative DNA damage in fish spermatozoa exposed to cadmium-Short communication. Acta Vet. Hung. 2016, 64, 120-124. [CrossRef] [PubMed]

67. Mercer, J.R.; Gray, K.; Figg, N.; Kumar, S.; Bennett, M.R. The methyl xanthine caffeine inhibits DNA damage signaling and reactive species and reduces atherosclerosis in ApoE(-/-) mice. Arter. Thromb. Vasc. Biol. 2012, 32, 2461-2467. [CrossRef] [PubMed]

(C) 2019 by the authors. Licensee MDPI, Basel, Switzerland. This article is an open access article distributed under the terms and conditions of the Creative Commons Attribution (CC BY) license (http://creativecommons.org/licenses/by/4.0/). 